\title{
HUBUNGAN ANTARA TEKANAN DARAH SISTOLIK DENGAN KADAR HBA1C PADA PASIEN DIABETES MELITUS TIPE 2 DI KLINIK ARAFAH LAMPUNG TENGAH
}

\author{
Resti Arania', Firhat Esfandiari², Tusy Triwahyuni ${ }^{3}$, Alif Rizky Hafizhdillah ${ }^{4}$ \\ ${ }^{1}$ Departemen Patologi Anatomi Rumah Sakit Abdul Moeloek Provinsi Lampung \\ ${ }^{2}$ Departemen IImu Penyakit Dalam Rumah Sakit Mardi Waluyo Kota Metro \\ ${ }^{3}$ Departemen Parasitologi Fakultas Kedokteran Universitas Malahayati \\ ${ }^{4}$ Program Studi Kedokteran Fakultas Kedokteran Universitas Malahayati \\ [email korespondensi: allifrizzky@gmail.com]
}

\begin{abstract}
Relationship Between Systemic Blood Pressure With Hba1c Levels in Type 2 Diabetes Mellitus Patients in Arafah Clinic Lampung Central. Diabetes mellitus (DM) is a collection of symptoms caused by a rise in blood glucose levels due to a gradual decline in insulin secretion and driven by insulin resistance. This study was aim to direct a good standard of $\mathrm{HbA1c}$ levels to people living with type 2 Diabetes Mellitus who have a history of hypertension at the Arafah Clinic, Central Lampung, in 2020. The design of this study used crosssectional, which means data collection was done during the research. The sampling technique was total sampling. Respondents in this study are patients with type 2 diabetes mellitus at the Arafah Clinic, Central Lampung, in 2020. The research instrument was a complete medical record of type 2 diabetes mellitus patients. In this study, the frequency distribution of the sex of type 2 diabetes mellitus patients was male 16 people $(34,8 \%)$, female 30 people $(65,2 \%)$. The frequency distribution of age in patients with type 2 diabetes mellitus was obtained 24-45 years 7 (seven) people $(15,2 \%), 46-65$ years 32 (Thirtytwo) people $(69,6 \%),>65$ years 7 people $(15,2 \%)$. The distribution of systolic blood pressure in type 2 diabetes mellitus patients with normal values $\leq 140 \mathrm{mmHg}$ was 34 people $(73,9 \%)$, with a height $>140 \mathrm{mmHg}$ was 12 people (261\%). The frequency distribution of HbA1c levels with normal $<9 \%$ was 21 people $(45,7 \%)$, with high levels $\geq 9 \%$ was 25 people $(54,3 \%)$. The chi-square statistical test results showed no relationship with the results $p=0.747(p>0.05)$. There was no relationship between systolic blood pressure and $\mathrm{HbA} 1 \mathrm{c}$ levels in patients with type 2 diabetes mellitus at the Arafah clinic, Central Lampung in 2020.
\end{abstract}

Keywords: Systolic Blood Pressure, HbA1c Levels, Diabetes Mellitus type 2

\begin{abstract}
Abstrak: Hubungan Antara Tekanan Darah Sistolik Dengan Kadar Hba1c Pada Pasien Diabetes Melitus Tipe 2 di Klinik Arafah Lampung Tengah. Diabetes Melitus (DM) adalah kumpulan gejala yang timbul pada seseorang disebabkan oleh karena adanya peningkatan kadar glukosa darah akibat penurunan sekresi insulin yang progresif dan dilatarbelakangi oleh resistensi insulin. Penelitian ini bertujuan untuk dapat mengarahkan standar Kadar HbA1c yang baik pada kehidupan penderita Diabetes Melitus tipe 2 yang memiliki Riwayat Hipertensi di Klinik Arafah Lampung Tengah tahun 2020. Desain penelitian ini menggunakan cross-sectional yaitu pengambilan data sewaktu penelitian. Teknik pengambilan sampel berupa total sampling. Responden dalam penelitian ini adalah pasien diabetes melitus tipe 2 di Klinik Arafah, Lampung tengah tahun 2020. Instrumen penelitian ini berupa rekam medik lengkap pasien diabetes melitus tipe 2 . Berdasarkan hasil uji statistic chi-square didapatkan tidak terdapat hubungan dengan hasil $p=0,898(p>0,05)$. Pada penelitian ini didapatkan distribusi frekuensi jenis kelamin pasien diabetes melitus tipe 2 laki laki sebanyak 16 orang $(34,8 \%)$, Perempuan sebanyak 30 orang $(65,2 \%)$. Distribusi frekuensi usia pada pasien diabetes melitus tipe 2 didapatkan 24-45 tahun sebanyak 7 orang $(15,2 \%)$, 46-65
\end{abstract}


tahun sebanyak 3 orang $(69,6 \%),>65$ tahun sebanyak 7 orang dengan $(15,2 \%)$. Distribusi tekanan darah sistolik pada pasien diabetes melitus tipe 2 dengan nilai normal $\leq 140$ mmhg sebanyak 34 orang $(73,9 \%)$, dengan Tinggi $>140 \mathrm{mmHg}$ sebanyak 12 orang $(26,1 \%)$. Distribusi frekuensi kadar HbA1c dengan normal $<9 \%$ sebanyak 21 orang $(45,7 \%)$, dengan kadar tinggi $\geq 9 \%$ sebanyak 25 orang $(54,3 \%)$. Hasil uji statistik chi-square didapatkan tidak adanya hubungan dengan hasil $p=0,747(p>0,05)$.

Kata Kunci: Tekanan Darah Sistolik, Kadar HbA1c, Diabetes Melitus tipe 2

\section{PENDAHULUAN}

Diabetes Melitus (DM) adalah kumpulan gejala yang timbul pada seseorang disebabkan oleh karena adanya peningkatan kadar glukosa darah akibat penurunan sekresi insulin yang progresif dan dilatarbelakangi oleh resistensi insulin (Fidyana dkk, 2020). Adapun pengertian menurut Perkumpulan Endokrinologi Indonesia (PERKENI), suatu kelompok penyakit metabolik dengan karakteristik Hiperglikemia karena kelainan sekresi insulin, kerja insulin atau keduanya. Resistensi insulin yang terjadi pada hati dan sel otot, sel beta pancreas yang gagal telah dikenal sebagai patofisiologi kerusakan sentral dari DMT2 (PERKENI, 2019).

DM diklasifikasikan menjadi empat tipe yaitu Diabetes Melitus tipe 1, Diabetes Melitus tipe 2, Diabetes Melitus Gestasional, dan Diabetes Melitus akibat lainnya (Suwinawati dkk, 2020). Adapun faktor risiko DMT2 yang tidak dapat berubah seperti jenis kelamin, umur, dan faktor genetik dan faktor risiko yang dapat diubah seperti kebiasaan merokok, tingkat pendidikan, pekerjaan, aktivitas fisik, konsumsi alkohol, Indeks Massa Tubuh, lingkar pinggang dan umur di atas 35 tahun (Fidyana dkk, 2020). DM adalah salah satu diantara penyakit tidak menular yang akan meningkat jumlahnya di masa datang (Fitrah, 2017). DMT2 menyumbang antara $90 \%$ dan $95 \%$ diabetes, dengan proporsi tertinggi di negara berpenghasilan rendah dan menengah (WHO, 2019). DMT2 saat ini menjadi epidemi global. Insiden dan prevalensi meningkat di negara berkembang dan negara industri baru, dampak terhadap kesehatan masyarakat di beberapa negara terdiri dari masalah sosial, seperti berkurangnya kualitas hidup dan berkurangnya kelangsungan hidup orang dengan DMT2, dan masalah ekonomi, seperti produktivitas yang berkurang dan biaya perawatan yang tinggi (Amorim et al, 2019).

Adapun pengertian dari American Diabetes Association (ADA) tentang DMT2, yang sebelumnya disebut sebagai DM tergantung non insulin atau DM onset dewasa, menyumbang 9095\% dari semua Diabetes. Bentuk ini meliputi individu yang memiliki kerabat defisiensi insulin dan memiliki resistensi insulin perifer. Ada berbagai penyebab DMT2. Meskipun etiologi spesifiknya tidak diketahui, kerusakan autoimun sel-b tidak terjadi dan pasien melakukannya tidak memiliki penyebab lain yang diketahui diabetes kebanyakan. Tapi tidak semua pasien DMT2 itu gendut dan mempunyai berat badan berlebihan (ADA, 2019). Menurut International Diabetes Federation (IDF) (2019), terkait kematian dan pengeluaran kesehatan DM di tingkat global, regional dan nasional, selain sumber yang resmi IDF mempunyai fungsi sebagai pengingat bagi pembaca klasifikasi DM dan diagnostik kriteria. Prevalensi global DM dalam 20-79 tahun kelompok usia diperkirakan Prevalensi yang terkena DM di Dunia sekitar 463 juta orang, angka ini diproyeksikan mencapai 578 juta orang di 2030, dan sekitar 700 juta orang di 2045. Diperkirakan untuk 2019 menunjukkan bahwa sekitar $8,8 \%$ dari populasi orang yang sudah dewasa pada usia 20 - 79 tahun menderita DM. Ini setara dengan 87,6 juta orang, $56,7 \%$ di antaranya tidak terdiagnosis.

Hampir setengah dari orang 
dewasa dengan DM dapat ditemukan di kota-kota. Sebagian besar di Wilayah Asia Tenggara biasanya tinggal di negara-negara berpenghasilan menengah dan sebagai Hasilnya 99,2\% orang dewasa dengan DM berada di negara tersebut (IDF, 2019). Jika dibandingkan dengan tahun 2013, prevalensi DM di provinsi Lampung berdasarkan diagnosa dokter pada umur $\geq 15$ tahun Riskesdas 2018 meningkat $0,7 \%$ mencapai di titik $1,4 \%$ (KEMENKES RI, 2019).

$$
\text { (WHO) World Health } \begin{array}{r}
\text { Organization } \\
\text { jumlah }
\end{array}
$$

penyandang DM pada tahun 2000-2030 mengalami kenaikan dari 10,3 juta menjadi sekitar 21,3 juta. Sedangkan International Diabetes Federation (IDF) menjelaskan bahwa pada tahun 20132017 terdapat kenaikan jumlah penyandang DM dari 10,3 juta menjadi 16,7 juta pada tahun 2045 (PERKENI, 2019). Indonesia menempati peringkat ke-5 di dunia, naik dua peringkat, IDF mengeluarkan data penyandang DM pada tahun 2013 bahwa Indonesia menempati peringkat ke-7 di dunia dengan jumlah sekitar 7,6 juta penyandang DM (PERKENI, 2015). Penyebab kematian di Indonesia tahun 2007, sekitar 59,5\% merupakan penyakit yang tidak menular (KEMENKES RI, 2019). Menurut Dinas Kesehatan provinsi Lampung tahun 2016 tercatat bahwa tahun 2009 DM menduduki peringkat ke-4 trend penyakit yang tidak menular menjadi penyebab kematian dengan angka 373 kasus (DINKES LAMPUNG, 2015).

Angka kejadian diabetes melitus di Provinsi Lampung untuk rawat jalan pada tahun 2009 perbulan rata-rata mencapai 365 orang dan mengalami peningkatan pada tahun 2010 menjadi 1.103 orang. Angka kejadian diabetes melitus di Kabupaten Lampung Tengah berdasarkan data di Dinas Kesehatan Lampung Tengah mengalami peningkatan sebesar $9 \%$ yaitu sebanyak 581 kasus (Zulfian dkk, 2020). Berdasarkan data primer BPJS Regio Metro yang peneliti dapatkan di tahun 2020, diabetes melitus dan hipertensi di wilayah Lampung tengah memiliki peringkat yang tertinggi dengan jumlah 11.614 pasien diabetes melitus dari 38.028 pasien diabetes melitus, dan pasien hipertensi dengan jumlah 54.118 dari 160.912 orang hipertensi.Di Lampung Tengah, Klinik Arafah memiliki banyak pasien aktif juga selalu menyelenggarakan beberapa kegiatan yang mendukung untuk para pasien. Klinik Arafah memiliki data diabetes melitus 820 orang sedangkan hipertensi 3.726 orang dan memperoleh pasien terbanyak di Lampung Tengah.

Hipertensi adalah salah satu yang menjadi penyebab utama kematian prematur di dunia. World Health Organization (WHO) memperkirakan prevalensi hipertensi secara global sekitar $22 \%$ dari total penduduk di dunia. Dari sejumlah penderita tersebut, hanya kurang dari satu perlima melakukan upaya pengendalian terhadap tekanan darah yang dimiliki. prevalensi sebesar $25 \%$ terhadap penduduk total yaitu Asia Tenggara. WHO memperkirakan 1 diantara 5 perempuan di seluruh dunia memiliki hipertensi sedangkan laki-laki 1 diantara 4. Menurut Laporan RISKESDAS tahun 2018 penduduk di Indonesia pada umur $>18$ tahun mengalami peningkatan prevalensi hipertensi dari sebelumnya sekitar $25.8 \%$ di tahun 2013 menjadi $34.1 \%$ di tahun 2018. Prevalensi di Provinsi Lampung tersendiri yaitu 29.9\% (KEMENKES, 2019). DM yang ditandai dengan hiperglikemia merupakan salah satu faktor resiko hipertensi (Fitrah, 2016).

Thawornchaisit \& Team (2013), melakukan penelitian di Thailand bahwasannya penderita DM memiliki resiko yang tinggi untuk menderita $\mathrm{HT}$. Laki-laki dan perempuan yang menderita penyakit DM akan lebih berisiko tinggi terkena HT. Silih (2012), melakukan penelitian di Pontianak Selatan bahwa DM memiliki resiko 1,7 kali lebih besar untuk terjadinya HT dibandingkan dengan yang tidak menderita DM. Gaol, dkk (2015) melakukan penelitian di Rumah sakit Martha Friska bahwa proporsi DM dengan HT pada tahun 2014 terdapat 
sebesar $38,7 \%$ yang termasuk proporsi tertinggi kedua di antara komplikasi lainnya. Zebua dkk (2016) melakukan penelitian di di RSUD Gunungsitoli bahwa proporsi DMT2 dengan HT sebanyak 33,1\% (Mardhia, 2020).

Begitu pula Astiari (2016), menyatakan bahwa DM dan HT sering kerap muncul bersamaan. Meskipun DM menyebabkan HT merupakan hal yang kompleks, DMT2 mempunyai risiko yang cukup besar untuk mengalami HT (Astiari, 2016). DM dengan HT ini termasuk penyakit yang ditakuti karena adanya penyakit ini akan memudahkan terjadinya komplikasi penyakit yang lain, seperti penyakit jantung koroner, stroke, dan lain-lain. Pengidap DM sangat perlu mengontrol glukosa darah, pengendalian glukosa darah dan pengidap DM bisa melihat dari dua hal yaitu pertama glukosa darah sesaat dan yang kedua glukosa darah jangka Panjang. Pemantauan glukosa darah sesaat bisa dilihat dari GD2PT, sedangkan pada glukosa darah Panjang

\section{METODE}

Penelitian ini menggunakan metode penelitian deskriptif analitik dengan pendekatan cross sectional. Penelitian ini dilakukan di Klinik Arafah Lampung Tengah Provinsi Lampung pada bulan Desember 2020 s.d Februari 2021. Populasi penelitian ini adalah bisa dilakukan menggunakan pemeriksaan yang lebih spesifik yaitu dengan pemeriksaan HbA1c (Putri dan Larasati, 2013).

Peneliti berpendapat bahwa pemeriksaan $\mathrm{HbA} 1 \mathrm{c}$ adalah Pemeriksaan yang dimana untuk menentukan kadar Haemoglobin yang berikatan dengan Glukosa darah dan untuk menentukan meningkat atau tidaknya kadar tersebut, secara kimia terglikasi dan untuk pemeriksaan HbA1c massa waktunya 3 bulan atau 120 hari sesuai dengan umur Haemoglobin. Berdasarkan uraian di atas, melihat banyaknya kasus HT dan DM di Indonesia, didukung dengan pentingnya pemeriksaan $\mathrm{HbA} 1 \mathrm{c}$ dan tingginya HbA1c yang merupakan faktor terjadinya HT sehingga Tekanan Darah Sistol meningkat pada penderita DM maka peneliti ingin meneliti hubungan antara Tekanan Darah Sistol dengan kadar HbA1c pada pasien DMT2 di Klinik Arafah Lampung Tengah.

seluruh pasien DM tipe 2 di Klinik Arafah tahun 2020. Sampel diambil dari pasien DM tipe 2 yang memiliki rekam medik kadar HbA1c di Klinik Arafah Lampung Tengah. Teknik Pengambilan Sampel yang digunakan total sampling.

HASIL

Didapatkan dari data rekam medik yang terdiagnosa Diabetes

Terdiri dari 16 Laki-Laki dan 30 Melitus tipe 2 dengan jumlah 46 pasien.

Perempuan.

Tabel 1. Analisis Data Univariat

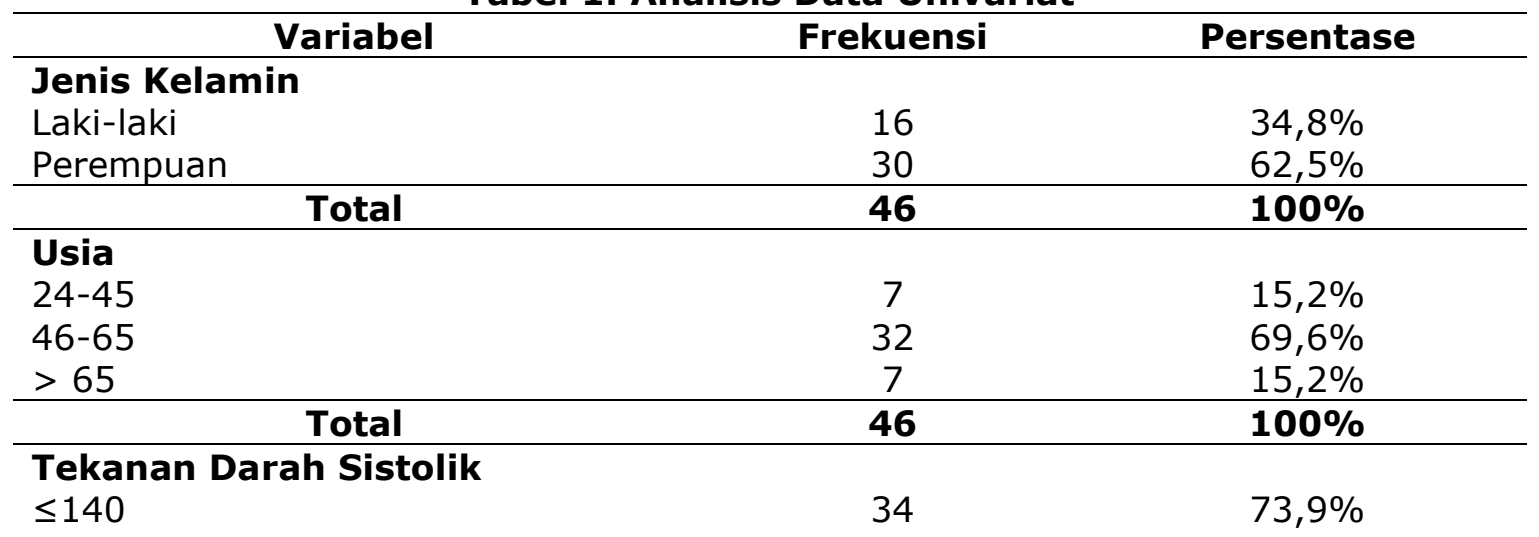




\begin{tabular}{llll}
$>140$ & & 12 & $26,1 \%$ \\
\hline & Total & $\mathbf{4 6}$ & $\mathbf{1 0 0 \%}$ \\
\hline $\begin{array}{l}\text { Kadar HbA1c } \\
<9 \%\end{array}$ & & \\
$\geq 9 \%$ & 21 & $45,7 \%$ \\
\hline \multicolumn{2}{r}{} & 25 & $54,3 \%$ \\
\hline
\end{tabular}

Berdasarkan Tabel 1 Diketahui bahwa Distribusi Frekuensi penderita DM tipe 2 berdasarkan Jenis Kelamin adalah 16 Laki-laki (34,8\%) dan 30 Perempuan $(65,2 \%)$, lalu berdasarkan usia adalah 24-45 tahun dengan jumlah 7 orang $(15,2 \%)$, 46-65 tahun jumlah 32 orang $(69,6 \%)$ dan $>65$ tahun jumlah 7 orang (15,2\%), Selanjutnya berdasarkan TDS yaitu $\leq 140 \mathrm{mmHg}$ dengan jumlah 34 (73.9\%) dan $>140 \mathrm{mmHg}$ dengan jumlah 12 (26.1\%) dan yang terakhir berdasarkan kadar HbA1c adalah yaitu $<9 \%$ berjumlah 21 orang $(45,7 \%)$ dan $\geq 9 \%$ berjumlah 25 orang $(54,3 \%)$.

Tabel 2. Analisis Data Bivariat

\begin{tabular}{cccccccc}
\hline \multirow{2}{*}{$\begin{array}{c}\text { Tekanan Darah } \\
\text { Sistolik }\end{array}$} & \multicolumn{4}{c}{ Kadar HbA1c } & Jumlah & \multirow{2}{*}{ Nilai p } \\
\cline { 2 - 7 } & \multicolumn{2}{c}{$<9 \%$} & \multicolumn{2}{c}{$\geq 9 \%$} & & \\
\cline { 2 - 7 } & $\mathrm{n}$ & $\%$ & $\mathrm{~N}$ & $\%$ & $\mathrm{n}$ & $\%$ & \multirow{2}{*}{0.747} \\
\hline 140 & 16 & 47,1 & 18 & 18 & 34 & 100 & \\
\hline 140 & 5 & 41,7 & 7 & 58,3 & 12 & 100 & \\
\hline Jumlah & 21 & 45,7 & 25 & 54,3 & 46 & 100 & \\
\hline
\end{tabular}

Hasil analisis data Tabel 2 menggunakan rumus chi-square dengan uji alternatif fisher exact dengan tingkat kesalahan (alpha) 0,05 didapatkan $P$ value $=0,787(\mathrm{P}>0,05)$, maka dapat

\section{PEMBAHASAN}

\section{Jenis Kelamin}

Berdasarkan tabel pengolahan data diatas dengan jumlah responden 46 orang dan diperoleh bahwa mayoritas responden berjenis perempuan yaitu sebanyak 30 orang $(65,2 \%)$. Hal ini senada dengan data Badan Litbang Kesehatan (2014) yang menyampaikan bahwa penderita DM meningkat sering dengan juga meningkatnya proporsi kegemukan. Yaitu ada kegemukan sebesar 18,8\% pada tahun 2007 menjadi $26,6 \%$ pada tahun 2013. Ironisnya kegemukan lebih tinggi daripada laki-laki dimana perempuan meningkat dari $14,8 \%$ pada tahun 2007 menjadi 32,9\% pada tahun 2013 , sedangkan laki-laki hanya $13,9 \%$ menjadi $19,7 \%$. Alhasil kenaikan DM pun lebih tinggi pada perempuan daripada laki-laki. Ada kesejahteraan, tetapi sepertinya masyarakat kita tidak disimpulkan bahwa tidak ada hubungan yang signifikan antara tekanan darah sistolik dengan kadar HbA1c pada pasien DM tipe 2 .

siap menghadapinya. Ini lebih kepada gaya hidup serba instan, makan yang berlebihan, dan jarang olahraga atau aktivitas fisik.

Menurut Ramadhan dkk (2018), pengendalian DM yang kurang baik sebagian besar pada responden perempuan, pada kelompok umur lansia, berpendidikan rendah dan menderita DM $<5$ tahun. Hanya tujuh responden dari keseluruhan responden yang hasil pemeriksaannya menunjukkan pengendalian DM yang baik.

Penelitian sebelumnya yang dilakukan oleh Mustipah pada tahun 2019 di Yogyakarta menyatakan bahwa dari 80 responden, jenis kelamin perempuan paling banyak yaitu sebanyak 53 orang $(66,2 \%)$ sisanya laki-laki yang berjumlah 27 orang $(33,8 \%)$ (Mustipah, 2019). 
Hasil penelitian lain juga menunjukan bahwa persentase pasien diabetes pada perempuan lebih besar dibanding laki-laki. Perempuan memiliki komposisi lemak lebih tinggi dibanding

\section{Umur}

Berdasarkan tabel pengolahan data diatas diperoleh bahwa mayoritas responden berumur 24-45 tahun yang memiliki jumlah frekuensi 7 orang responden dengan persentase $(15,2 \%)$. Berumur 46-65 tahun frekuensi 32 orang responden dengan persentase $(69,6 \%)$. Berumur $>65$ tahun frekuensi 7 orang dengan persentase (15,2\%). Umur berkaitan dengan kenaikan kadar gula dalam darah, sehingga semakin meningkatnya umur seseorang maka gangguan toleransi glukosa seseorang tersebut akan semakin tinggi.

Hasil penelitian ini sama dengan hasil penelitian Komariah dan Rahayu (2020) yang menunjukkan bahwa penderita diabetes melitus tipe 2 paling banyak dialami pada pasien usia 46-65 $(69,4 \%)$. Begitu pula pada penelitian di Klinik Dokter Praktik Mandiri Hakikiyah Lampung Tengah tahun 2019 menunjukan bahwa prevalensi DM yang berusia $<45$ tahun hanya 7 orang $(12,5 \%)$ dan usia $\geq 45$ tahun sebanyak 49 orang $(87,5 \%)$ (Zulfian dkk, 2020).

$\mathrm{Hal}$ ini menunjukkan bahwa diabetes sering kali muncul setelah seseorang memasuki usia rawan, terutama setelah usia 45 tahun. Seseorang dengan usia lebih dari 45 tahun memiliki peningkatan risiko terhadap terjadinya DM dan intoleransi glukosa yang disebabkan oleh faktor degeneratif yaitu menurunnya fungsi tubuh, khususnya kemampuan dari sel beta dalam memproduksi insulin, sehingga kadar glukosa darah meningkat (Purwanti dkk, 2016).

\section{Tekanan Darah Sistolik}

Berdasarkan tabel pengolahan data diatas diperoleh bahwa mayoritas responden kadar tekanan darah sistolik normal $(\leq 140 \mathrm{mmHg})$ berjumlah 34 orang $(73,9 \%)$ sedangkan kadar tekanan darah sistolik tinggi (>140 $\mathrm{mmHg}$ ) sebanyak 12 orang $(26,1 \%)$.

Tekanan darah merujuk kepada tekanan yang dialami darah pada laki-laki, sehingga perempuan lebih mudah gemuk yang berkaitan dengan risiko obesitas dan diabetes (Komariah, 2020).

pembuluh arteri ketika darah dipompa oleh jantung ke seluruh anggota tubuh manusia. Diketahui bahwa tekanan darah dapat disebabkan oleh beberapa faktor, antara lain usia, jenis kelamin, penyakit penyerta, faktor keturunan, faktor demografi (Winta dkk, 2018).

\section{Kadar HbA1c}

Pembentukan HbA1c terjadi dengan lambat yaitu selama 120 hari, yang merupakan rentang hidup sel darah merah. HbA1c dalam bentuk 70\% terglikolisasi (mengabsorbsi glukosa). Jumlah hemoglobin yang terglikolisasi bergantung pada jumlah glukosa yang tersedia (Kee J1, 2013). Berdasarkan hasil pengolahan data diatas, diketahui bahwa rerata dari distribusi kadar HbA1c adalah dengan jumlah frekuensi tertinggi 25 orang $(54,3 \%)$ yaitu kadar HbA1c yang tidak terkontrol baik.

Hasil pemeriksaan hemoglobin A1C merupakan pemeriksaan tunggal yang sangat akurat untuk menilai status glikemik jangka panjang dan berguna pada semua tipe penyandang DM. pemeriksaan ini bermanfaat bagi pasien yang membutuhkan kendali glikemik (Soewondo, 2014).

\section{Hubungan antara Tekanan Darah Sistolik dengan Kadar HbA1c}

Untuk mengetahui hubungan antara variabel bebas dan variabel tergantung dilakukan uji Chi Square atau Fisher exact melalui crosstabulasi. Hasil cross tabulasi antara kadar HbA1c dengan tekanan darah sistolik dapat dilihat pada tabel 2 hasil cross tabulasi memiliki tingkat kebermaknaan yang tidak signifikan yakni 0,787 ( $p>0,05)$.

Dan dari hasil uji hipotesis komparatif pada Fisher Exact menyatakan tidak terdapat hubungan kadar HbA1c dengan tekanan darah sistolik. Hal ini ditunjukan dari nilai significancy $\geq 0,05$. Berdasarkan hasil yang diperoleh dari uji deskriptif, pada pasien DM tipe 2 dengan kadar HbA1C yang mendominasi adalah pasien 
dengan tekanan darah sistolik normal. $\mathrm{Hal}$ ini berbanding lurus dengan hasil uji hipotesis komparatif pada Fisher exact yang mengemukakan tidak adanya hubungan antara kadar $\mathrm{HbA} 1 \mathrm{c}$ dengan tekanan darah sistolik.

\section{Keterbatasan penelitian}

Keterbatasan penelitian ini salah satunya karena pengambilan data rekam medik dalam desain cross sectional dilakukan dengan kondisi pandemi covid-19. Dimana data hanya ada sedikit dan pasien DM takut untuk datang ke Fasilitas Kesehatan, sehingga sampel dalam penelitian ini tidak banyak. Semua variabel diukur menurut keadaan atau status penderita yang diambil dari rekam medis pada saat observasi dan sampel pasien DMT2 yang mengalami hipertensi hampir semua aktif dalam pengobatan.

\section{KESIMPULAN}

Berdasarkan analisa dan pembahasan diatas, tidak terdapat hubungan antara tekanan darah sistolik dengan kadar HbA1c pada pasien Diabetes Melitus tipe 2 di Klinik Arafah Lampung Tengah.

\section{SARAN}

$\begin{array}{ccc}\text { Masyarakat } & \text { agar } & \text { lebih } \\ \text { memperhatikan } & \text { kesehatan } & \text { salah }\end{array}$ satunya dengan pembatasan asupan makanan untuk menurunkan kadar lipid sebagai preventif yang berpotensi penyakit diabetes. Dan melakukan gerakan hidup sehat dengan melakukan senam satu kali dalam seminggu atau bisa dengan olahraga jenis lainnya. Perlu dilakukan penelitian yang lebih luas cakupan faktor yang mempengaruhi kadar kolesterol pada pasien DM sehingga dapat menjadi suatu pertimbangan atau perbandingan untuk perencanaan program.

\section{DAFTAR PUSTAKA}

ADA. (2019). Standards Of Medical Care In Diabetes 2019. The Journal of Clinical And Applied Research And Education 42.

Amorim, M. M. A., Souza, A.H., Coelho, A. K. (2019). Competences for Self-Care and Self-Control in
Diabetes Mellitus Type 2 in Primary Health Care. Worl Journal of Diabetes 10(8): 454-462. doi: 10.4239/wjd.v10.i8.454.

Astiari, N.P.T. (2016). Faktor-Faktor Yang Mempengaruhi Kejadian Hipertensi Pada Laki-Laki Dewasa Di Puskesmas Payangan, Kecamatan Payangan Kabupaten Gianyar. [Skripsi]. Bali: Universitas Udayana.

Badan Litbang Kesehatan. (2014). Riset Kesehatan Dasar 2013. Jakarta: Badan Litbang Kesehatan.

Dinkes Lampung. (2015). Rencana Strategis Dinkes Provinsi Lampung Tahun 2015-2019. Available at: https://dinkes.lampungprov.go.id/ wp-

content/uploads/2016/07/1.RENST RA-DINAS-KESEHATAN-PROVINSILAMPUNG-2015-2016.pdf.

Fidyana, M, Esfandiari, F., Maharyuni, E., dan Nur, M. (2020). Hubungan Indeks Massa Tubuh dengan Kadar HDL pada Pasien Diabetes Mellitus Tipe 2. Jurnal IImiah Kesehatan Sandi Husada 11(1): 392-396. doi: $10.33860 /$ jik.v13i2.46.

Fitrah, A. (2017). Hubungan Kadar Gula Darah Dengan Tekanan Darah Pada Pasien Diabetes Melitus Tipe2 Di Rumah Sakit Umum Pusat Haji Adam Malik Tahun 2016. [Skripsi]. Medan: Universitas Sumatera Utara.

Gaol, R.I., Hiswani, dan Ashar, T. (2015). Karakteristik Penderita Diabetes Mellitus dengan Komplikasi yang di Rawat Inap di Rumah Sakit Martha Friska Tahun 2014. Jurnal USU 1(4): 1-10.

IDF. (2019). Diabetes Atlas.

Kemenkes RI. (2019). Hari Diabetes Sedunia Tahun 2018. Pusat Data dan Informasi Kementerian Kesehatan RI, pp. 1-10.

Kemenkes RI. (2019). Hipertensi Si Pembunuh Senyap. Kementerian Kesehatan RI, pp. 1-5. https://pusdatin.kemkes.go.id/res ources/download/pusdatin/infodati n/infodatin-hipertensi-sipembunuh-senyap.pdf. 
Komariah \& Rahayu, S. (2020). Hubungan Usia, Jenis Kelamin dan Indeks Massa Tubuh dengan Kadar Gula Darah Puasa pada Pasien Diabetes Melitus tipe 2 di Klinik Pratama Rawat Jalan Proklamasi, Depok, Jawa Barat. Jurnal Kesehatan Kusuma Husada 11(1): 41-50.

Mardhia, I. (2020). Karakteristik Penderita Diabetes Mellitus Tipe 2 Dengan Komplikasi Yang Dirawat Inap Di Rumah Sakit Umum Pusat Haji Adam Malik Medan Tahun 2018. [Skripsi]. Medan: Universitas Sumatera Utara.

Mustipah, O. (2019). Analisis FaktorFaktor Intrinsik yang Mempengaruhi Self Care pada Pasien DM Tipe 2 di Puskesmas Depok III Sleman Yogyakarta. Yogyakarta: Universitas 'Aisyiyah.

PERKENI. (2015). Panduan Pengelolaan Dislipidemia di Indonesia: 1-51.

PERKENI. (2019). Pedoman Pengelolaan Dan Pencegahan Dm Tipe 2 Dewasa Di Indonesia 2019: 1133.

Purwanti, N. W. N. A., Jirna, I. N. \& Arjani, I. A. M. S. (2016). Analisis Hubungan Kadar Gula Darah Puasa dengan Kadar Kolesterol High Density Lipoprotein (HDL) pada Pasien Diabetes Melitus tipe 2 di RSUP Sanglah. Meditory 4(2): 65-71.

Putri, A. E. S. dan Larasati, T.A. (2013). Hubungan Obesitas dengan Kadar HbA1c Pasien Diabetes Melitus Tipe 2 di Laboratorium Patologi Klinik Rumah Sakit Umum Daerah Abdul Moeloek Provinsi Lampung. Medical Journal of Lampung University 2(4): 1-10.

Ramadhan, N., Marissa, N., Fitria, E., \& Wilya, V. (2018). Pengendalian diabetes melitus tipe 2 pada pasien di Puskesmas Jayabaru Kota Banda Aceh. Media Penelitian dan Pengembangan Kesehatan 28(4): 239-246.

Silih, Y. (2012). Hubungan Antara Diabetes Mellitus dengan Kejadian Hipertensi di Kecamatan Pontianak Selatan. [Naskah Publikasi].
Pontianak: Universitas

Tanjungpura Pontianak.

Soewondo, P. (2014). Harapan Baru Penyandang Diabetes Melitus Pada Era Jaminan Kesehatan Nasional 2014. Jurnal IImiah Kesehatan 2(1).

Suwinawati, E., Ardiani, H., Ratnawati, R. (2020). Hubungan Obesitas dengan Kejadian Diabetes Melitus Tipe 2 Di Pos Pembinaan Terpadu Penyakit Tidak Menular Puskesmas Kendal Kabupaten Ngawi. Journal of Health Science and Prevention 4(2): 80-84. Available at: http://doi.org/10.29080/jhsp.v4i2. 388.

Thawornchaisit, P.L. and Team, T.C.S. (2013). Health Risk Factor and Prevalence of Hypertention. Global Journal of Health Science 5(4): 121-126.

WHO. (2019). Classification of Diabetes Mellitus.

Winta, A. E., Setiyorini, E. \& Wulandari, N. A. (2018). Hubungan Kadar Gula Darah dengan Tekanan Darah pada Lansia Penderita Diabetes Tipe 2. Jurnal Ners dan Kebidanan 5(2): 163-171.

Zulfian, Esfandiari, F., Anggraeni, A., dan Selviani, A. (2020). Hubungan Antara Indeks Massa Tubuh Dengan Kadar Trigliserida Pada Pasien FKTP Diabetes Melitus Tipe II di Dokter Praktik Mandiri KHakikiyah Lampung Tengah Agustus 2019. Jurnal Medika Malahayati 4(1): 1-8. 